\title{
Access to Czech Social Survey Data*
}

\author{
JINDR̆ICH KREJČí $* *$ \\ Institute of Sociology, Academy of Sciences of the Czech Republic, Prague
}

\begin{abstract}
The article presents practical information on the sources of Czech social survey data for both researchers interested in data on Czech society and data professionals interested in the state of the art of data services. Czech survey research was deeply affected by the communist regime, but underwent intense development in 1960s and after the revolution in 1989. In the field of official statistics, data services are provided by the Czech Statistical Office. The Sociological Data Archive (SDA) of the Institute of Sociology provides data from quantitative sociological surveys, promotes data dissemination and secondary analysis and supports large research projects (e.g. ISSP, ESS). The Czech Archive of Qualitative Data and Documents at the Masaryk University and Soft Data Archive MEDARD at the Virtual Institute provide data services for qualitative social research. A number of public domain data sets remain under the responsibility of academic and governmental research institutions. It is also possible to access the data of private research agencies. Czech data are accessible also via international data services.
\end{abstract}

Sociologický časopis/Czech Sociological Review, 2002, Vol. 38, No. 6: 809-826

The organising of services specialising in disseminating and archiving computerised social science data first started out in the United States in the late 1950s and in Western Europe in the $1960 \mathrm{~s}^{1}$. Today, social science data archives have become a standard and international requisite part of the infrastructure for social research.

The benefits are clear. The archive increases the effect of the investment into social research many times over. It is a source of data, scientific information and related services. Simultaneously, it enables the continued use of the outcome of research projects. At present large collections of data located in many data organisations around the world are easily available to social researchers via any computer connected to the Web. National data services are integrated into networks and thus support international co-operation and com-

\footnotetext{
* Work on this article was supported by grant No. K9058117 'Current Czech Society and Questions of European Integration' from the Programme for the Development of Basic Science Research of the Academy of Sciences of the Czech Republic, and the TSER Project 'Towards a European System of Social Reporting and Welfare Measurement' financed by the European Commission.

** Direct all correspondence to: Jindřich Krejčí, Institute of Sociology, Academy of Sciences of the Czech Republic, Jilská 1, 11000 Prague 1, e-mail: krejci@soc.cas.cz

${ }^{1}$ The oldest publicly accessible archive was founded in the Roper Center in the USA in the late 1950s. The oldest European archive is the Zentralarchiv für empirische Sozialforschung (ZA) in Cologne, Germany, which was established in 1960.
} 
parative research in the social sciences [see Mochmann 1998 and 1999, Lane 1990]. Another important benefit stems from the provision of easy access to research materials for educational purposes.

This article is devoted to the situation in the development of social science data services in the Czech Republic. The main objective is to give an account and brief description of the existing sources of Czech survey research data which are available for secondary analysis in sociology. It should provide practical information for both researchers interested in Czech social data and data professionals interested in the state of the art of Czech data services.

To prepare this text I have drawn on and summarised previous work I have done tracing the establishment of the Sociological Data Archive of the Institute of Sociology of the Academy of Sciences and the formation of the institutional infrastructure of the Czech social sciences [Krejči 2001, 2002a, 2002b], and taking stock of publicly available crosssectional databases in the Czech Republic (technical reports on surveys made within the project EuReporting). ${ }^{2}$ Information in the article is closely tied to and extends Večerník's state-of-the-art report on Czech social reporting, survey research and data on transformation, which was published in the Czech Sociological Review 38/3 [Večerník 2002]. The information on data sources in this article also includes a number of Web links, which for technical reasons are not presented directly in the text but can be found in the Web References section at the end of the article.

\section{The history of Czech social survey research}

Czech empirical social research has a long tradition. The first empirical surveys were conducted in the 1930s. Questionnaire surveys were organised particularly as a part of case studies, e.g. the sociological survey of the village Velké or the survey of citizens of the city of Brno (both organised by I. A. Bláha). The first programme for a systematic survey of attitudes was created in 1946 at the Czechoslovak Institute for Public Opinion Research, the foundation of which was inspired by the existence of the American Gallup Institute.

Unfortunately, the impact of the communist regime on the social sciences was disastrous. In the 1950s sociology was considered a bourgeois pseudo-science and anything reminiscent of sociological research was abolished, though sample surveys continued to be conducted in the field of socio-economic research as part of the official statistics of the Statistical Office.

During the years of the political 'thaw' in the 1960s, empirical research underwent intense development, particularly in the second half of the decade. The Institute of Sociology of the Czechoslovak Academy of Sciences was established in 1965. In 1967 the

\footnotetext{
${ }^{2}$ TSER Project 'Towards a European System of Social Reporting and Welfare Measurement' was internationally directed by Dr. Heinz-Herbert Noll from ZUMA, Mannheim, and the national coordinator was Jiři Večerník from the Institute of Sociology, Academy of Sciences of the Czech Republic, Prague.
} 
Institute for Public Opinion Research was re-established, which revived the post-war research tradition. Applied research projects were launched in the field of the sociology of enterprise and work. The development culminated in a large-scale project $(13,215$ interviews) called the Survey on Social Differentiation and Mobility, carried out in 1967 by a team of researchers from the Institute of Social and Political Sciences, led by Professor Pavel Machonin in co-operation with a number of Czech and Slovak sociologists from many other institutions [Machonin et. al 1969]. This project established the tradition of Czech social mobility and stratification surveys, which continues to date.

After the Soviet occupation in 1968, the period of 'normalisation' put a halt to the promising development of the social sciences. Some research activities were placed under the direct control of the communist party (e.g. the research programme of the Institute for Public Opinion Research), while others were banned altogether. Some topics of research simply were not needed in the conditions of 'really existing socialism'. The Institute of Sociology was abolished and only a small department of sociology was set up within the Institute of Philosophy and Sociology. In contrast to Poland, Hungary and Yugoslavia, Czech sociologists were not allowed to participate in international comparative surveys. Nonetheless, socio-economic surveys continued to be conducted, including official statistics (Federal Statistical Office) and economic opinion polling (Research Institute of Trade, University of Economics in Prague etc.). There were also several studies on the family, leisure time activities and culture, and two large-scale stratification surveys (Class and Social Structure 1978 and 1984), following up on the research from 1967.

After the political change in 1989, empirical social research underwent another sharp change in development. A large number of projects in academic research, public opinion polling and also in commerce were implemented. The Czech Republic also became involved in international research activities. The development of survey research primarily resulted from the liberalisation of what had been a restricted environment and from

Table 1. Structure of intramural R\&D expenditures and R\&D personnel in the Czech Republic in 2000

\begin{tabular}{lc|c|rrrr}
\hline & \multicolumn{2}{c|}{ Intramural expenditures } & \multicolumn{4}{c}{ Personnel in FTE ${ }^{2)}$ in thousands } \\
\cline { 2 - 7 } & $\begin{array}{c}\text { in thousands } \\
\text { of EUR }{ }^{1)}\end{array}$ & $\%$ & researchers & $\begin{array}{c}\text { researchers } \\
\text { in } \%\end{array}$ & $\begin{array}{c}\text { employees } \\
\text { total }\end{array}$ & $\begin{array}{c}\text { employees } \\
\text { in \% }\end{array}$ \\
\hline Natural sc. & 185928 & 25.0 & 4429 & 32.0 & 6926 & 28.6 \\
Technical sc. & 438793 & 59.0 & 6202 & 44.8 & 11864 & 49.0 \\
Medical sc. & 51546 & 6.9 & 909 & 6.6 & 1596 & 6.6 \\
Agricult.sc. & 34905 & 4.7 & 929 & 6.7 & 1785 & 7.4 \\
Humanities & 24024 & 3.2 & 1072 & 7.7 & 1552 & 6.4 \\
Social sc. & $\mathbf{8 8 2 8}$ & $\mathbf{1 . 2}$ & $\mathbf{3 1 1}$ & $\mathbf{2 . 2}$ & $\mathbf{4 7 5}$ & $\mathbf{2 . 0}$ \\
\hline TOTAL & 744024 & 100.0 & 13852 & 100.0 & 24198 & 100.0 \\
\hline
\end{tabular}

Notes:

1) $1 \mathrm{EUR}=35,6 \mathrm{CZK}$ (average rate in 2000)

2) full time equivalent (FTE) work in $R \& D$

Source: Czech Statistical Office [Ukazatele..., 2000]. 
an increase in the public need for research information. This need has continued to grow as Czech democracy and economic growth has gradually stabilised and the country has come to be included in European and global structures. On the other hand, Czech social sciences are generally still quite small in scale. During the communist regime, this field was impoverished more than the technical and natural sciences were, and it has not yet succeeded in re-establishing for itself an appropriate position. This may be gleaned also from Table 1, which contains data about investments and the number of employees in the fields of research and development. Expenditures for the social sciences in 2000 amounted to only $1.2 \%$ of the total $R \& D$ expenses, and the proportion of employees working in the social sciences is $2 \%$ of the total.

\section{Available data}

The outcome of the pre-war and early post-war research can be found in some publications dating from that time, e.g. in two sociological journals: Sociologická revue [The Sociological Review] and Sociální problémy [Social Problems]. Machine-readable data files have been produced since the 1960s. Unfortunately much of the data, which were usually stored on punch cards, did not survive the ensuing period of neglect. An exception is the survey Attitudes of Citizens to Politics from 1968, which was keyed again from original questionnaires [see Seidlová 2000]. The Sociological Data Archive (see below) provides access to several files from the 1970s and 1980s. There are stratification surveys - Class and Social Structure 1978 and 1984 (also known as Social Structure and Mobility Surveys) - and the first survey of a longitudinal panel study on the professional careers of primary-school students - Family (1988-1998). Some other surveys of the Institute of Public Opinion Research and the Institute for Philosophy and Sociology from that period are also stored in the SDA, but the quality of their documentation and formats are problematic. The results of a number of surveys, including works of the Institute of Public Opinion Research, socio-economic research of the Research Institute of Trade, and other institutions, are available in survey reports and publications stored in archives (CVVM, Central State Archive; see References on the Web).

In comparison with the past Czech survey research after 1989 has produced a great deal of data, but unfortunately not very systematically. Regular social reporting and social indicator research has not yet become well established [see Večerník 2002]. No national general social survey or similar project has been organised in the Czech Republic and cross-sectional surveys are exceptional.

In addition to the official statistics there are only a few national studies, which have been repeated at least three times and their data are publicly available: Economic Expectations and Attitudes were surveyed biannually in 1990-1992 and annually in 1993-1998, the survey on Social Justice was repeated three times in the Czech Republic (1991, 1995, 1999), the programme of Social Structure and Mobility Surveys (see above) continued as a part of the large international project Social Stratification in Eastern Europe after 1989 from 1993, the longitudinal panel study Family (also mentioned above) was conducted again in 1992, 1993/1994 and 1998. The largest collection of regularly measured attitudes of Czechs to- 
wards political, economic and social issues comes from the programme of monthly quota, sample-based surveys of the Institute of Public Opinion Research (1990-2000) and the Centre of Public Opinion Research (since 2001).

The lack of local systematic and regular surveys has been partially overcome by Czech participation in international programmes. Since 1990 the Czech Republic has taken part in most of the existing programmes of continual comparative research, i.e. the ISSP - International Social Survey Programme (annually since 1992), European and World Values Surveys (1990, 1991, 1995, 1999), NDB - New Democracies Barometer (1991, 1992, 1993, 1995, 1998), Central-East Eurobarometer (annually 1990-1997), Candidate Countries Barometer (since 2001), and CSES - Comparative Study of Electoral System (1996, 2002). A new project, the European Social Survey, has just been launched. Unfortunately, the Czech Republic has not taken part in any international household panel projects.

In addition to the above-mentioned titles of cross-sectional research there have also been many one-shot studies, both local and international, official statistical surveys, as well as of course official statistical surveys. Information on available data is provided by the data archives and other organisations, a description of which follows below.

\section{Data services in the Czech Republic}

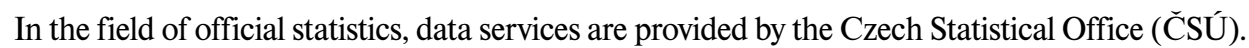
Statistics services concentrate in particular on the distribution of research results, but under certain conditions primary data from sample surveys are made available.

In the field of academic research, data services were slow in arriving. Projects for the systematic archiving of data have been rare even within individual institutes. Most data remained in possession of individual research teams. Nevertheless, the idea of archiving data has a long tradition. The need and the technical resources necessary to store and distribute electronic data files through a data archive first appeared at the end of the 1960s [see Illner 1968]. The period of normalisation, however, affected this promising development: social research was suppressed and there was also fear that the communist regime might abuse the archived data. Nonetheless, at the end of the 1970s a thematic archive was established, which focused on stratification surveys conducted in 1978 and 1984 [see Matějovský et al. 1979]. In 1990 this archive was destroyed during the re-structuralisation of the former Institute of Philosophy and Sociology. Some of the materials were preserved by users of the archive and are today stored in the Sociological Data Archive.

After 1989 the idea of a national data archive again became popular and several projects were considered in this regard. In September 1998 the Sociological Data Archive (SDA) was opened at the Institute of Sociology, Academy of Sciences of the Czech Republic. Its foundation was realised within the large-scale project Social Trends (Research - Archives - Publication - Graduate Training). Recently, two qualitative data archives were also established. The Czech Qualitative Data and Documents Archive at Masaryk University in Brno was created in 1999. The MEDARD Soft Data Digital Archive was founded in 2000 and is part of the Virtual Institute in Prague. 
The date of establishment put the SDA at the end of first wave of development of data services in post-communist Central and Eastern Europe. ${ }^{3}$ In 2001 the Czech archive became a member of the Council of European Social Sciences Data Archives (CESSDA) and has participated in the international co-operation of data organisations and the system of data transfers. The establishment of the Czech qualitative data archives was inspired by the Qualidata Archive in the UK and was connected to the recent rapid development of this internationally, relatively new activity in social data archiving.

Unfortunately, since Czech data services are young many data files which could be made publicly available still remain under the responsibility of research teams and institutions. The academic, governmental and commercial research institutions as sources of data available for academic research are mentioned hereafter.

\section{Official statistics}

The Czech Statistical Office (see References on the Web) provides three regular statistical sample surveys:

- The Microcensus is a regular income survey conducted since 1958. Until 1989 the survey was repeated every 3-5 years on a 1-2 \% random sample of households. The Microcensus 1992 was organised in March 1993, when a $0.5 \%$ sample of Czech households was queried. The Microcensus 1996 surveyed $1 \%$ of Czech households in March 1997. The next survey is planned for early 2003.

- The Family Expenditure Survey has also been conducted since 1958. The selection of about 2000-3500 of Czech households is based on quota sampling (economic activity). Respondent households provide daily records of incomes and expenditures.

- The Labour Force Survey is a quarterly survey of approximately 0.7 \% of Czech households. Regular surveying started in 1993 and is based on EUROSTAT standards.

Results of the surveys are published in periodicals and specialised publications of the ČSÚ. The complete list of publications and selected tables and analysis are available via the Internet. It is also possible to access Czech Statistical Office microdatabases but it must be negotiated on an individual basis after contacting the Office. Several data modules from the surveys organised by the ČSÚ are parts of the international programmes of EUROSTAT and CEPS/INSTEAD and are available via international data services of these organisations (see References on the Web).

\footnotetext{
${ }^{3}$ The first social data archive in Central and Eastern Europe was the Hungarian data archive of consortium TÁRKI, which was established in 1985, i.e. during the socialist era. In the 1990s archives were organised in Estonia (1996), Slovenia (1997), and the Czech Republic (1998). Now the networks of data archives and data archiving activities cover nearly all of Europe - both East and West [see Hausstein 2001, Web pages of EDAN and CESSDA].
} 


\section{Sociological Data Archive (SDA)}

The main objective of the SDA (see References on the Web) is to make Czech sociological data publicly available for academic, educational and other non-commercial purposes. There are three main areas of activities of the Archive:

- acquiring, archiving and providing data files

- promoting data dissemination and secondary analyses

- $\quad$ supporting special research projects

The SDA collects computerised files of data from quantitative sociological surveys. Its holdings include public domain data collected by the Institute of Sociology and other Czech organisations conducting state-financed sociological research, data from Czech public opinion polls and from international surveys with Czech participation. For an example of available data see the Table 2 .

An electronic data catalogue and access to services is provided via the Internet. Selected data files can be downloaded on-line (Czech data from the ISSP 1992-1997 and international Social Stratification in Eastern Europe After 1989). Other data are available after ordering and undertaking conditions of usage (both can be made via the Internet and fax). Data are free of charge, but only for non-commercial research or educational purposes. Many of the materials are in two language versions - Czech and English. Data is offered in SPSS format and it may also be transferred to several other formats on request.

Archived data remains the property of the depositor and their secondary users are required to uphold relevant copyrights. In the Czech Republic all activities in survey research are based on strict legislation concerning the protection of personal data. The Act on the Protection of Personal Data [Act No. 101/2000] is based on and fully compliant with the European Commission's Regulation 95/46/EC. Therefore all data offered by the Archive are anonymous and users must refrain from any attempts to identify respondents.

The following specifics of the Czech environment are crucial for the development of data services:

- the tradition of using data services is underdeveloped,

- in some fields there is basically no accompanying social research infrastructure (information services, methodological centres).

The problem of how to increase the use of secondary data analysis is not only a problem of the data services being offered, but also of demand. Researchers are not really aware of existing possibilities. Data services, whether domestic or international, are used less than they should be. Few projects include secondary data analysis as an important element of their research strategy. The comparison of investments into surveys and the number of published analyses therefore often gives evidence on inefficiency. If, for example, we browse through the archived data sets, we discover that in some cases there are only two or three publications related to a particular data file and that portions of several surveys have not been processed at all. The SDA therefore pays close attention to the dissemination of information on data services and to generally supporting secondary data analysis. It publishes information in periodicals, participates in teaching programmes at universi- 
Table 2. Examples from the data holdings of the Sociological Data Archive, Prague

Czech data sets from the ISSP

1992-2001
Complete versions of Czech data from the International Social Survey

Programme (ISSP): Social Inequality - Czechoslovakia 1992 (ISSP 1992),

Attitudes towards Environment and Local Politics (ISSP 1993), Family (ISSP 1994), National Identity (ISSP 1995), Role of the Government (ISSP 1996), Work Orientations 1997 (ISSP 1997), Religion (ISSP 1998, in Czechia fielded in 1999), Social Inequality and Justice (ISSP 1999), Environment (ISSP 2000), and Social Networks (ISSP 2001). Data sets include ISSP modules as well as Czech national specific sections. (Czech and English versions)

International data sets from the ISSP 1985- 1996 including merged national modules ISSP from participating countries are provided by the SDA only for local users. (English versions)

\begin{tabular}{|c|c|}
\hline $\begin{array}{l}\text { Social Consequences } \\
\text { of Transition } 1995 \\
\text { (SOCO) }\end{array}$ & $\begin{array}{l}\text { Database of comparative household survey created under the aegis of } \\
\text { Social Costs of Economic transformation in Central Europe (SOCO) } \\
\text { initiated and co-ordinated by the Institute for Human Sciences, Vienna. } \\
\text { The survey was conducted in the Czech Republic, Hungary, Poland, } \\
\text { Slovakia, and the new federal states of Germany in 1995. It is focused to } \\
\text { the main aspects of economic and social transformation - job changes, } \\
\text { housing, income, social securities and attitudes towards the economic } \\
\text { situation, the expected role of the state, social inequalities, etc. (English } \\
\text { version) }\end{array}$ \\
\hline
\end{tabular}

Economic A semi-annual (1990-1992) and annual (1993-1997) survey of the

Expectations Institute of Sociology. Between 1990 and 1994 it was conducted in both and Attitudes the Czech and Slovak Republics, since 1995 only in Czechia. The survey 1990-1998 (EEA) focuses on opinions about the economic situation on the macro- and micro level. (Czech and English versions)

Social Stratification The SSEE General Population Survey was conducted in Bulgaria, the in Eastern Europe Czech Republic, Hungary, Russia and Slovakia in 1993 (approx. 5,000 reafter 1989 spondents) and in Poland in 1994 (approx. 3,500 respondents). Over-samples (about 1,500) were carried out in Prague and Warsaw for purposes of specialised urban research. It is focused to social stratification and mobility change after 1989.

\section{Czech Election Data Exit Poll 1992 and 1996 (Czech and English versions)}

24 Hours before the Elections - The Chamber of Deputies 1996: Conducted during the 24 hours before the elections, organised by the SC\&C, commissioned by the Czech Television. (Czech and English versions)

24 Hours before the Elections - Senate 1996: Three surveys conducted on a panel of respondents before the first and second round and after election to the Senate. The survey was conducted by the SC\&C and commissioned by the Czech Television. (Czech and English versions)

Trends 04/98 and Trends 05/98: Data from two modules of questions fielded for the party Union of Freedom. They were attached to periodical survey organised by the STEM and focused on political parties and their preelection campaigns. (Czech and English versions) 


\begin{tabular}{ll}
\hline IVVM/CVVM & Data from the programme of regular monthly surveys organised by the \\
1990-2001 & IVVM (Institute for Public Opinion Research) in 1990-2000 and CVVM \\
& (Centre for the Public Opinion Research] since 2001 and focused on atti- \\
& $\begin{array}{l}\text { tudes to political, economical and social issues in Czech society. (Czech } \\
\text { versions) }\end{array}$ \\
\hline
\end{tabular}

Czechoslovak Social The social stratification and mobility surveys focused on economic and soStructure and cial positions of the head of the household and other active members, baMobility Surveys sic mobility data of all adult persons, income, housing conditions, leisure 1978 and 1984 time, attitudes and value orientations. (1978: Czech version; 1984: Czech and English version)

\begin{tabular}{ll}
\hline $\begin{array}{l}\text { Ten Years of Social } \\
\text { Transformation } \\
\text { in the Czech } \\
\text { Republic, 1999-2000 }\end{array}$ & $\begin{array}{l}\text { Large stratification and mobility study. It also focused on opinions about } \\
\text { social change and the process of transformation. Among the topics ad- } \\
\text { dressed are the evaluation of social changes, education and skills, social } \\
\text { position and job career, household composition and level of living, life- } \\
\text { style and social networks, political attitudes and attitudes to the transfor- } \\
\text { mation and modernisation process. (Czech and English versions) }\end{array}$ \\
\hline Family '89-'98 & $\begin{array}{l}\text { The longitudinal panel survey. The original intention was to observe life } \\
\text { and professional career of children leaving the primary school. The main } \\
\text { waves of the interviewing occurred in 1989 (children and parents), 1992 } \\
\text { (parents), 1993-1994 (children finishing the secondary school) and 1998 } \\
\text { (children and parents). (Czech version) }\end{array}$
\end{tabular}

Source: SDA, Institute of Sociology.

ties, and organises presentations and workshops. The Archive also publishes a quarterly information bulletin entitled SDA Info (in Czech only).

Since its launch the SDA has often been queried about things not directly concerned with the provision of data. Therefore, on-line services were expanded to include: 1) a directory of links to sources of social data, Czech and foreign centres of social research, and general information on the Czech Republic, and 2) on-line access to analytical publications of the Institute of Sociology.

The Archive also contributes to the creation of support for organising some research projects. This involves, in particular, Czech surveys of the International Social Survey Programme (ISSP) and the just-launched European Social Survey (ESS). It also contributed to the Czech part of other projects, such as the International Social Justice Project (ISJP), Second International Adult Literacy Survey (SIALS) and the European Values Study (EVS), though to a lesser extent.

\section{Qualitative data}

The basic aim of qualitative data archives is the systematisation, digital processing and preservation of available materials in the field of qualitative social research [see Corti, Foster and Thompson 1995]. Internationally the development of qualitative data archiv- 
ing started in the second half of the 1990s. It was connected to technological development and the rapid decrease of the price of computer memory. In addition to past technological difficulties, qualitative data also requires a greater effort with respect to the protection of personal data, and for this reason the control over access to the data is stricter. Many materials stored in the qualitative archives are usually made available only when permission is given by the author of the materials. Often, only systematically processed information on existing materials and not the data themselves are gathered. Another problem is the documentation of the context of surveys. For the purposes of archiving, the modification of research plans and additional expenses are often necessary during fieldwork and the processing of materials. Given the difficulties mentioned here the interest of researchers in data services and deposition is less than in the case of quantitative data.

The organisation of both Czech qualitative data archives was inspired by Qualidata at the University of Essex in the UK. The first such archive, the Czech Archive of Qualitative Data and Documents (see References on the Web), is more ambitiously conceived, and its principal aim is to preserve Czech qualitative data in the field of sociological and socio-psychological research, and to gather information on their availability in the Czech Republic [Katrňák 1999]. Its mission also includes archiving incidentally occurring data. The archive has been active for four years, states the number of materials stored, and includes a register of information on the availability of organised materials. On the other hand, access to the information on the content of the archive is somewhat complicated, because it requires personal contact. The Archive's Internet pages include only general information.

The MEDARD Archive (see References on the Web) seems to be more active. Its foundation originally resulted from the research activities of the Virtual Institute and should also serve its programme of on-line education in the social sciences. Nevertheless the archive is also open to the general public and seeks acquisitions outside the programmes of the Institute. The on-line accessible catalogue includes information on materials from several research projects. There are also Web links to the archives of the Czech press, other available materials for qualitative social research, and a database of on-line accessible literature. A good deal of information is devoted to methods of digitalisation of materials for social research and their preservation. Also specialised software for digitalisation and processing of qualitative data is accessible via MEDARD's pages. Unfortunately, most of the materials are available only in the Czech language.

\section{Academic and governmental research institutions}

Most state-financed research is organised within the Academy of Sciences of the Czech Republic (see References on the Web). The Academy of Sciences was established by the state and its activities are largely financed from the state budget; nevertheless, it is not a service organisation for the government. The objective of the Academy is to create an independent environment for basic research. Elected bodies confirm individual research programmes. The Academy of Sciences now consists of 60 research and 7 service institutions. Unfortunately this system results also in the separation of most research from higher education. 
Five institutions, the Institute of Sociology, the Economics Institute/CERGE, Masaryk Institute, the Institute of Psychology and the Institute of State and Law belong to the socio-economic division of the Academy of Sciences. The first two organisations are crucial to the production of survey data. The Institute of Sociology (see References on the Web) is one of the main centres of empirical sociology in the Czech Republic and probably the largest producer of public domain survey data. The research programme includes a number of topics. ${ }^{4}$ The Institute is the Czech representative in the ISSP and ESS and is a member of the international organisations ECSR, IPSA, ECPR. Since 2001 it has also included a survey organisation, the CVVM - Centre for Public Opinion Research (see References on the Web). A joint institute of the Academy of Sciences and Charles University, CERGE (Centre for Economic Research and Graduate Education; see References on the Web), is active in the field of socio-economic research. CERGE also plans to establish its own archive of socio-economic data in the near future.

In the Czech Republic there are three main centres of higher education in empirical sociology. The Faculty of Social Studies of Masaryk University (see References on the Web) in Brno continues its long tradition as an important centre of both theoretical and empirical sociological studies. Despite the above-mentioned division of research and education it has organised and participated in many important surveys. The Faculty of Social Sciences of Charles University (see References on the Web) is much younger. It was founded in 1990, but it specialises more in empirical research. Another centre is the Department of Sociology of the Faculty of Philosophy of Charles University in Prague. In addition to these three schools, sociological and socio-economic surveys are organised also in many other faculties and universities, especially in departments of sociology, economics and political science. Specialised social research is developed also, for example, at the Czech University of Agriculture or the Faculty of Science of Charles University, and there also exist specialised centres such as the already mentioned Virtual Institute (see References on the Web), which has intensively cultivated qualitative social research. A complete list of Czech institutions of higher education is available on the Internet (see References on the Web).

The Czech government and its ministries established a number of specialised analytical centres and councils, which are active in organising surveys for decision-making purposes in politics. There also exist large governmental research institutions, such as the Research Institute of Labour and Social Affairs (RILSA; see References on the Web), which deals with research on the labour market and welfare, and the Institute for Information on Education (see References on the Web), which specialises in research on education and participates in large-scale international surveys comparing the efficiency of education (PISA, TIMSS, PIRLS, etc.).

\footnotetext{
${ }^{4}$ Research departments: Centre for Public Opinion Research, Czech Border Regions, Economic Sociology, Gender and Sociology, Local and Regional Politics, Public Opinion as a Social Phenomenon, Social Stratification, Sociological Data Archive, Sociology of Politics, Transformation of the Social Structure, Value Orientations in Society.
} 


\section{Private research agencies}

However much most of the private research activities are oriented primarily towards marketing, there are also projects of use and accessible to academic research. Several agencies have launched their own social-survey projects and provide results for publication in the media, while a number of private subjects have actively participated in academic research projects and many agencies collaborate in academic and state-funded projects as fieldwork sub-contractors. The possibilities for using data from originally commercially oriented surveys in academic research have resulted in the collaboration of marketing and academic institutions. Table 3 includes the list of agencies and their Web addresses.

In the Czech Republic the largest research agency is AISA. In the 1990s it collaborated on a number of important social research projects, e.g. World Values Survey, New Democracies Barometer, Central-East Eurobarometer etc., but it now concentrates nearly entirely on market research.

STEM and Taylor Nelson Sofres Factum (TNS Factum) together with the abovementioned, state-financed CVVM are probably the best-known opinion polling agencies. This is because the results of their polls are published regularly in the media. In 1993 STEM launched a programme called Trends, which conducts regular monthly public opinion polls on 'hot issues'. The survey focuses on party preferences, and political and economic opinions and it facilitates research on social trends with respect to numerous questions. In addition to regular publication in the media, two books have also been published: Czech Society in 1998 [Hartl, Huk and Haberlová 1999] and Where to Now? [Hartl et al. 2000]. In 1994 a similar programme of regular polls was launched by Factum-non Fabula, a predecessor of TNS Factum. In 1994 the survey was conducted monthly, in 1997 biweekly, and at present it is conducted on a weekly basis. Data from both surveys have also been used in a number of academic publications and have become an important source for the analysis of social trends in the Czech Republic.

Another company, SC\&C, has established close co-operation with academic institutions and has taken an active part in several important projects: e.g. Secondary International Adult Literacy Survey (SIALS) and European Values Study (EVS, in 1999). With regard to the EVS the agency has also provided its own data services on the Internet (in the Czech language, URL: see SC\&C in Table 3).

The MML - TGI (Market \& Media \& Lifestyle - Target Group Index) is one of the largest commercial research projects in the Czech Republic. It is co-ordinated by MEDIAN. The co-operation between MEDIAN and the Institute of Sociology of the Czech Academy of Sciences resulted in the publication of an analysis of lifestyle during the economic transformation [Friedlanderová, Tuček and MEDIAN 2000].

The results of election studies are among the more popular topics published in the media. In addition to regularly surveying party preferences (regular polls by STEM, TNS Factum and CVVM), special studies are also organised on every public election. STEM, TNS Factum, SC\&C, MEDIAN, and the state-founded CVVM are particularly active in the organisation of pre- and post-election surveys. Several data files from election studies are available from the SDA (see Table 2). 
Table 3. Social research, public opinion polling and marketing research agencies in the Czech Republic

\begin{tabular}{|c|c|}
\hline Name Web & address \\
\hline$\overline{A C ~ N i e l s e n ~ C ̌ R ~}$ & http://www.acnielsen.com/cz/ \\
\hline AGMA & http://www.agma.cz \\
\hline AISA & http://www.nfoaisa.cz \\
\hline AMAR Marketing & http://www.amar.cz \\
\hline Amasia & - \\
\hline AVE Marketing & http://www.ave.cz \\
\hline Consumer Data & http://www.consumerdata.cz \\
\hline FOCUS - Center for Social and & \\
\hline Marketing Analysis & http://www.focus-agency.cz \\
\hline Gallup Organization ČR & http://www.gallup.cz \\
\hline GfK Praha & http://www.gfk.cz \\
\hline IBRS - International Business & \\
\hline $\begin{array}{l}\text { and Research Services } \\
\text { In Line }\end{array}$ & $\begin{array}{l}\text { http://www.ibrs.cz/ } \\
\text { http://www.inline.cz }\end{array}$ \\
\hline INCOMA Research & http://www.incoma.cz \\
\hline INRA Praha & http://www.inra.cz \\
\hline Kleffman a Partner ČR & http://www.kleffmann.cz \\
\hline Marcom & http://www.marcom-praha.cz/ \\
\hline Mareco & http://www.mareco.cz \\
\hline Markent & http://www.markent.cz \\
\hline Median & http://www.median.cz \\
\hline Millward Brown & http://www.millwardbrown.com \\
\hline Network Media Services & http://www.nms.cz \\
\hline Opinion Window & http://www.research-int.com/ \\
\hline RCA Research & http://www.rca-research.com \\
\hline $\mathrm{SC} \& \mathrm{C}$ & http://www.scac.cz \\
\hline STEM & http://www.stem.cz \\
\hline STEM/MARK & http://www.stemmark.cz \\
\hline Tambor & http://www.tambor.cz \\
\hline Taylor Nelson Sofres Factum & \\
\hline Taylor Nelson Sofres Media & http://www.tnsofres.cz \\
\hline TIMA Liberec & http://www.tima-liberec.cz \\
\hline Universitas & http://www.universitas.cz/ \\
\hline Ultex & http://www.ultex.cz \\
\hline XUXA & http://www.xuxa.cz \\
\hline
\end{tabular}

Sources: Database of the project Quality of Surveys of Voting Preferences, Institute of Sociology; Strategie [Marketingový výzkum 2001]; SIMAR.

Notes: The list includes selected agencies concerned with social research, public opinion polling or market research. Small and specialised research agencies are not listed. In addition to the Czech branch office of the Gallup Organisation, all companies reported disposing of their own network of inquirers.

Listed Web addresses were active in December 2002. 


\section{International data services and Czech data}

The SDA is a member of the pan-European organisation CESSDA. Thus the Archive is integrated into a system of international data transfers and can provide its clients with data stored in other member organisations. In the same way, researchers from abroad also have improved access to Czech data. Unfortunately this system is not very user friendly and lacks any data catalogue shared by all participating archives and any standardised documentation of data.

The idea to launch a single pan-European data archive appeared in the $1960 \mathrm{~s},{ }^{5}$ but it was not successful. In pre-Internet times national archives had the advantage of closer contact with both data users and data producers. The International Data Catalogue (IDC, see References on the Web) was launched by CESSDA in 1996 and it represented a large step forward towards the international integration of data services. At present it includes information on the data holdings of 10 archives $^{6}$. The SDA's data library is not referred. Nevertheless, using the IDC it is possible to obtain information on a variety of Czech data from international surveys which are stored in archives abroad. Unfortunately the information included in the IDC is not standardised and the older technology behind the catalogue does not offer the convenience of current tools.

NESSTAR (see References on the Web) is a new Internet tool providing a networked infrastructure for social data dissemination. It was just recently launched and it is a tool that makes it possible to search, access control, analyse and download data and other materials via the Internet (see Ryssevik 1999, Lach 2002). At present only five data archives provide services via NESSTAR: UK Data Archive, NSD - Norway, DDA - Denmark, ADP - Slovenia, and RODA - Romania. For inclusion in NESSTAR it is necessary to uphold the documentation standard DDI (Data Documentation Initiative, see Ryssevik 1999) and to adopt new XML technology. Several other data archives, including Czech SDA, intend to do this and join the project in the near future.

International data sets with Czech data are also available in many other international and national data organisations. The largest data library in the world is in the ICPSR (Inter-university Consortium for Political and Social Research, see References on the Web) at the University of Michigan. CESSDA membership organisations as well as several non-European archives can be accessed via a map located on CESSDA's Web page (see References on the Web). The information on available or emerging data services in Central and Eastern Europe is provided on the Web pages of the East European Data Archives Network (EDAN; see References on the Web).

In addition to the data archives, several international research projects have organised their own data services, and Czech data are also available through these sources. The Centre for the Study of Public Policy at the University of Strathclyde (see References on the Web),

\footnotetext{
${ }^{5}$ The 'Central Archive' ZA in Germany was originally intended to become an international, pan-European data archive.

${ }^{6}$ BDSP - France, DDA - Denmark, UK Data, SSD - Sweden, SSDA - Israel, Steinmetz - Netherlands, TÁRKI - Hungary, ZA - Germany, and ICPSR - USA.
} 
in co-operation with Hungarian TÁRKI, have launched services which allow for the on-line analysis of data from the New Democracies Barometer surveys from 1990-1995. Data from the Social Stratification in Eastern Europe after 1989 (SSEE) are available on the project pages, which are located on the sites of the ISSR in Los Angeles and the SDA (see References on the Web). The data from the questionnaire surveys of the Comparative Study of Electoral Systems (CSES), together with the macro-data, are available on the special project pages (see References on the Web). The Family and Fertility Survey can be ordered through the on-line system of the PAU UNECE (see References on the Web). The CEPS/INSTEAD (see References on the Web) provides remote access via e-mail into otherwise confidential and protected data from sample surveys of statistical offices. It is possible to order an analysis of Czech data from the Luxembourg Income Study (LIS) and the Luxembourg Employment Study (LES). The Czech data provided for the use of the European Commission are accessible through the services of EUROSTAT (see References on the Web).

Some services do not offer direct access to data but only to 'meta-data'. The metadata are 'data on data', i.e. they include information on the character of the data sets and their availability. The very useful idea behind these services is to put order into a large quantum of data sources and offered information. They usually arrange information in a different way than data archives do and thus extend the possibilities for their use in research. The project EuReporting (see References on the Web) offers thematic information about European comparative official micro-data and academic cross-national and crosssectional databases. The arrangement of meta-data is based on social indicators, i.e. the system can search for available social indicators across different databases. The World Database of Happiness (see References on the Web) presents available information concerning surveys on the subjective appreciation of life, including distributions of responses to questions. The recently launched project NESSIE (Network of Economic and Social Sciences in Europe; see References on the Web) plans to establish a service for easy and effective access to European comparative survey research data.

\section{Conclusion}

The importance of the social research infrastructure has risen significantly in recent years. On the one hand, the extensive development of social research and international co-operation and the general demand for social data require an adequate background. On the other hand, new technology brings services closer to researchers and increases its contribution to the efficiency of social research. Archives have also become a basis for international networking and concentration in the social sciences.

In the European Union the promotion of infrastructure including data archives is considered to be one of the effective tools for implementing R\&D policy [see Warner 2001]. The situation in the Czech Republic is different. Official support programmes pay only a small amount of attention to the development of the social research infrastructure and there is a lack of local sources for the continued financing of projects focusing on infrastructure. The establishment of data services resulted out of the demand from researchers and pressure from abroad. Nevertheless, in the future we can expect the gradual 
development of data services and other infrastructures in connection with international trends. Full-scale involvement in international networks will be a new, qualitative step forward with respect to the range, comfort and efficiency of services. The main benefit of international co-operation lies in data exchange, the gradual interconnection of data services, joint work in developing IT technologies and the possibilities of sharing results, standardisation, and joint policy concerning the further development of services and gathering of support. At the same time, this also opens new channels for co-operation in social research.

JINDR̃ICH KREJČI graduated in sociology from the Faculty of Social Sciences of Charles University in Prague in 1996 (MA). He is head of the Sociological Data Archive (SDA) of the Institute of Sociology of the Academy of Sciences, Prague and participates in international surveys of the International Social Survey Programme (ISSP) and European Social Survey (ESS). His research focuses on social inequalities, political participation and the assessment of the quality of survey data. In 1999 and 2001 he taught a course on sources of social data and data management at the Faculty of Social Sciences of Charles University in Prague.

\section{References on the Web}

Academy of Sciences of the Czech Republic (AV ČR, Akademie věd České republiky): http://www.cas.cz (Czech, English)

Centre for Public Opinion Research (CVVM, Centrum pro výzkum veřejného mínění): http://www.cvvm.cas.cz (Czech)

Central State Archive (Ústřední státní archiv): http://www.mvcr.cz/archivy/index.htm (Czech)

CEPS/INSTEAD (Centre d'Études de Populations, de Pauvreté et de Politiques

Socio-Économiques / International Networks for Studies in Technology): http://www.ceps.lu/ (English)

CERGE - EI (Centre for Economic Research and Graduate Education - Economics Institute): http://www.cerge-ei.cz/ (English)

CESSDA - Council of European Social Science Data Archives: http://www.nsd.uib.no/cessda/ (English)

CSES - Comparative Study of Electoral Systems: http://www.umich.edu/ nes/cses/ (English)

CSPP - Centre for the Study of Public Policy: http://www.cspp.strath.ac.uk/ (English)

Czech Archive of Qualitative Data and Documents (Český archiv kvalitativních dat a dokumentů): http://www.fss.muni.cz/qarchiv/ (Czech, English)

Czech Statistical Office (ČSÚ, Český statistický úřad): http://www.czso.cz/ (Czech, English, German, French)

East European Data Archive Network (EDAN): http://www.gesis.org/en/cooperation/data_service/eastern_europe (English)

EuReporting project: http://www.gesis.org/en/social_monitoring/social_indicators/EU_Reporting/ (English) 
EUROSTAT: http://europa.eu.int/comm/eurostat/ (English, French, German)

Faculty of Social Sciences of the Charles University in Prague (FSV UK, Fakulta sociálních věd Univerzity Karlovy v Praze): http://www.fsv.cuni.cz/ (Czech, English)

ICPSR - Inter-university Consortium for Political and Social Research: http://www.icpsr.umich.edu/ (English)

Institut for Information on Education (ÚIV, Ústav pro informace ve vzdělávání): http://www.uiv.cz (Czech, basic information also in English)

Institute of Sociology of the Academy of Sciences of the Czech Republic (SoÚ AV ČR, Sociologický ústav Akademie věd České republiky): http://www.soc.cas.cz (Czech, English)

International Data Catalogue (IDC): http://dasun3.essex.ac.uk/Cessda/IDC/ (English)

ISSR - Institute for Social Science Research at the University of California in Los Angeles: http://www.sscnet.ucla.edu/issr/da/index.html (English)

List of Czech higher education institutions: http://www.education.cz/vs/ (Czech)

MEDARD (Soft Data Digital Archive, Digitální archiv měkkých dat): http://www.soc.cas.cz/trends/ (Czech, parts also in English)

NESSIE - Network of Economic and Social Sciences in Europe: http://nessie.essex.ac.uk/ (English)

NESSTAR - Networked Social Science Tools and Resources: http://www.nesstar.org (English)

PAU - Population Activities Unit of the United Nations Economic Commission for Europe: http://www.unece.org/ead/pau/

Research Institute of Labour and Social Affairs (RILSA - VÚPSV, Výzkumný ústav práce a sociálních věcí): http://www.vupsv.cz/ (Czech, English)

Faculty of Social Studies of the Masaryk University in Brno (FSS MU, Fakulta sociálních studií Masarykovy univerzity v Brně): http://www.fss.muni.cz/ (Czech, English)

Sociological Data Archive (SDA, Sociologický datový archiv): http://archiv.soc.cas.cz/ (Czech, English)

Virtual Institute (Virtuální institut): http://virtualni.institut.cz/ (Czech, English)

World Database of Happiness (Continuous register of scientific research on subjective appreciation of life): http://www.eur.nl/fsw/research/happiness/ (English)

\section{References}

Act No. 101 of April 4, 2000 on the Protection of Personal Data and on Amendments to Some Related Acts. Version translated for the Office for Personal Data Protection. URL: http://www.uoou.cz/eng/index.php3

Alan, Josef, Tomáš Bitrich, Zdeněk Konopásek. 2000. "Digitalní archiv měkkých dat MEDARD” [The Digital Archive of Soft Data MEDARD]. SDA Info 3/2000.

Friendlanderová, Hana, Milan Tuček and MEDIAN. 2000. Češi na prahu nového tisíciletí [Czechs on the Threshold of a New Millenium]. Praha: Sociologické nakladatelství.

Hartl, Jan et al. 2000. Kudy kam? Deset let po listopadu v prìzkumech STEM [Where to Now? Ten Years after November 1989 in the Surveys of STEM]. Praha: STEM.

Hartl, Jan, Jan Huk,, Věra Haberlová. 1999. Česká společnost 1998 [Czech Society in 1998]. Praha: Management Press. 
Hausstein, Brigitte (ed.). 2001. Social Science Data Archives in Eastern Europe. Köln: ZA. URL: http://www.gesis.org/en/data_service/eastern_europe/news/NAF2001.pdf

Illner, Michal. 1968. "Archiv společensko vědních informací - nový pomocník empirické sociologie" [Archive of Social Science Information - the New Assistant of Empirical Sociology]. Sociologický časopis 4: 507-510.

Katrňák, Tomáš. 1999. "Český archiv kvalitativních dat a dokumentů” [The Czech Archive of Qualitative Data and Documents]. SDA Info 3/1999.

Krejčí, Jindřich. 2001. "The Czech Sociological Data Archive”. IASSIST Quarterly 25, No. 2: 6-8. On-line version: http://datalib.library.ualberta.ca/publications/iq/iqvol25.html

Krejčí, Jindřich. 2002. "Datové služby pro českou sociologii” [Data Services for Czech Sociology]. Sociologický časopis 38: 125-138.

Krejčí, Jindřich. 2002. Establishing the Sociological Data Archive in the Czech Republic. In Social Science Data Archives in Eastern Europe, ed. by Brigitte Hausstein and Paul de Guchteneire.

Berlin, Cologne, Paris: Ferger Verlag.

On-line version: http://www.unesco.org/most/SSDAEEbook.pdf

Lach, Jiří. 2002. "NESSTAR: operace s daty přes internet” [NESSTAR: Operations with Data via the Internet]. SDA Info 2002/1-2: 10-12.

Lane, Jan-Erik. 1990. "Data Archives as en Instrument for Comparative Research".

In: Comparative Methodology. Theory and Practice in International Social Research. Ed. by Else $\emptyset$ yen. SAGE Publications.

Machonin, Pavel et al. 1969. Československá společnost [Czechoslovak Society]. Bratislava: Epocha.

Marketingový výzkum [Marketing Research]. 2001. Special supplement of Strategie 17. 9. 2001.

Matějovský, Antonín, J. Hudeček, H. Jeřábek, J. Ježek, V. Stupka, M. Tuček, A. Vodáková, J. Voženílek. 1979. Metodika výzkumu tř́dní a sociální struktury ČSSR 1978 [The Methodics of the Class and Social Structure Survey, CSSR 1978]. Praha: Filozofický a sociologický ústav ČSAV.

Mochmann, Ekkehart. 1998. European Cooperation in Social Science Data Dissemination. IFDO Net: http://www.ifdo.org/archiving_distribution/index_bfr.htm

Mochmann, Ekkehart. 1999. European Infrastructure Needs for Comparative Socio-economic Research. Paper presented on the European Socio-economic Research Conference in Bussels, 28-30 April 1999.

Ryssevik, Jostein. 1999. "Providing Global Access to Distributed Data Through Metadatata Standardisation - The Paralel Stories of NESSTAR and the DDI." Paper given at the UN/ECE Work Session on Statistical Metadata, Geneva, September 1999.

URL: http://www.nesstar.org/papers/

Seidlová, Adéla. 2000. "Postoj občanů k politice v roce 1968" [An Attitude of Citizens to Politics in 1968]. SDA Info 1/2000: 6-8.

Ukazatele výzkumu a vývoje za rok 2000 [Indicators of Research and Development for the year 2000]. 2001. Praha: Český statistický ústav.

Večerník, Jiří. 2002. "Monitoring the Transition in the Czech Republic: Data, Surveys and Studies”. Sociologický časopis/Czech Sociological Review 38: 365-379.

Warden, Campbell (ed.). 2001. Reflections on the role of Research Infrastructures in the European Research Area. Luxembourg: European Commision, Office for Official Publications of the European Communities. 